\title{
戸建て住宅用免震部材の地震時応答性状に関する 3 次元振動台実験 SHAKING TABLE TESTS ON RESPONSE CHARACTERISTICS OF SEISMIC ISOLATION SYSTEMS FOR HOUSES SUBJECTED TO 3-DIMENSIONAL EARTHQUAKE MOTIONS
}

\author{
飯 場 正 紀*，緑川光 正** \\ Masànori IIBA and Mitsumasa MIDORIKAWA
}

\begin{abstract}
Lessons learned from the 1995 Hyogoken Nanbu earthquake and the excellent performance of seismically isolated structures during the earthquake have persuaded the application of seismic isolation systems to houses. Because of a light weight of houses sliding and rolling types of isolators have been developed. A purpose of this paper is to verify the behaviors of seismic isolation systems under 3-directional recorded earthquake ground motions. 3-dimensional shaking table tests on full-scale seismic isolation systems with different types of isolators were conducted. In this paper, the effects of earthquake motions with 2-horizontal and vertical components on the response characteristics of the seismic isolation systems are discussed.
\end{abstract}

Keywords : Seismic isolation, Shaking table test, 2-horizontal earthquake motions, Vertical earthquake motion, Response of isolation system 免震構造、振動台実験、2 方向水平地震動、鉛直動、免震層応答

1.はじめに

1995 年 (平成 7 年) 兵庫県南部地震では、発生時刻が午前 6 時前 であったために、住宅の構造的な被害 1あるいは家具等の家財の転 倒・倒壊・破損 ${ }^{2} に よ よ る$ 死傷者が多かったことが報告されている。 また神戸市北区に建設されていた免震建築物の観測結果から免震建 策物の上部構造の最大加速度が基礎のそれに比べて小さくなる結果 や近傍の非免震建築物との比較から、免震効果が確認されている ${ }^{3)}$ 。 このような背景から、戸建て住宅の免震化に関する研究 4).5) ととも に戸建て免震住宅の実用化を目指した現象解明がなされているの。 戸建て住宅の場合、重量が小さいことから、すべり系支承や転がり 系支承の免震部材を利用する場合が多い6)-88。水平 1 方向地震動によ る種々の住宅用免震部材あるいは戸建て兔震住宅の振動台実験 6),9,10)から、いずれの免震部材でも、免震層上部での最大水平加速度 态答值が、免震層下部でのそれに比べて低减する免震効果が報告さ れている。

実際の地震動に対応した、水平2 2 次元や鉛直動も含めた 3 次元で

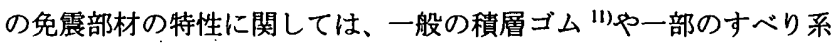
支承 ${ }^{6} に$ 関する研究により、入力地震動の速度あるいは免震層の水 平変位が水平面内で最大となる方向 (主軸方向) での応答が支配的で あることや鉛直動の影響は極めて小さいことが報告されている。

本論文では、機構の異なる免震部材の地震時挙動を統一的に把握 することを目的として、建設省土木研究所(現在、独立行政法人土木 研究所)の 3 次元大型振動台 ${ }^{12)}$ を利用し、兔震試験体の3 次元振動台
実験を行った ${ }^{13), 14)}$ 。水平 1 方向、2 方向、さらに鉛直動を含めた 3 方向地震動における免震試験体の水平加速度応答や水平変位応答結 果から、免震層の最大応答值や免震部材の力学特性に及ぼす地震動 の影響について検討を加えた。

\section{2. 免震試験体と免震部材}

図 1 に示す免震試験体を作製し、振動台上に設置した。免震試験 体は、免震部材とそれに支持される重量部で構成される。重量部の 大きさは、長辺 $5.64 \mathrm{~m}$ 、短辺 $2.82 \mathrm{~m}$ である。重量部はH形銅 (H-250x250x9x14)を主部材とし、H形鋼フレームの間には鉛を詰め た角型鋼管を配置している(H形鋼フレームも含めて質量約 9.9ton)。 その上部には、鋼板 4.枚(約 6.0ton)を載せている。この重量部を長辺 方向に 3 個ずつ設固した計 6 個の免震部材で支持している。

振動台実験に用いた免震部材の概要を図 2 に示す。図中に示した 等価周期や等価粘性减衰定数の值は設計值である。これらの免震部 材は、以下のような条件の下に設計されている。a)免震部材 1 台当 りの長期鉛直支持荷重は 20-30kN とする。b) 1995 年兵庫県南部地震 における神戸海洋気象台の地震動記録 NS 成分を最大速度 $50 \mathrm{~cm} / \mathrm{s}$ と した地震動入力時の免震層の最大水平変位を $10-15 \mathrm{~cm}$ とする。 i)免震部材 R(転がり支承)

ボールベアリングと高堿衰積層ゴム(ゴム層は 2 層)を組み合わせ て作られている。ボールベアリングは鉛直荷重支持機能を、高减衰 積層ゴムは復元機能と堿衰機能を有している。ベアリング部はリン
注）本論文の一部は既に文献13)において発表されている。

* 国土交通省国土技術政策総合研究所

建築新技術研究官・博士 (工学)

** 独立行政法人建築研究所 研究専門役.工博
Research Coordinator for Advanced Building Technology, National Institute for Land and Infrastructure Management, Dr. Eng.

Research Coordinator of Building Technology, Building Research Institute, Dr. Eng. 
グ状の高堿衰積層ゴムにより外気と遮断されている。

ii)免震部材 S(すべり支承)

2 面(2 段式)のすべり面を有する免震部材であり、安定した鉛直支 持能力とすべり特性を有する。比較的剛性の高い高堿衰積層ゴムを 取り付け、静摩擦から動摩擦への滑らかな移行を特徵とする。

iii)免震部材 $\mathrm{T}$ (転がり支承)

ボールベアリングと高堿衰積層ゴム(ゴム層は多層で、内側でつな がっている)を組み合わせて作られている。ボールベアリングは鉛直 荷重支持機能を、高減衰積層ゴムは復元機能と減衰機能を有してい る。ベアリング部はリング状の高堿衰積層ゴムにより外気と遮断さ れている。

iv)免震部材U(すべり支承)

振り子運動の原理を応用した球面すべり支承(Friction Pendulum System、FPS)であり、上下 2 枚の部材（球面板）と可動子から構成 されている。球面板の摺動面には特殊コーティングが施されており、 低摩擦化を図っている。

v)免震部材W(ゴム弾性支承)

高减衰積層ゴムとオイルダンパーを併用した部材である。水平方 向の剛性は鉛直方向の剛性の $1 / 1000$ 以下と非常に小さい。また座屈 に対する安定性を向上させるために、座屈防止具を取付け、 $\pm 250 \mathrm{~mm}$ の水平変形に対して鉛直荷重が保持できる。

\section{3. 振動台実験}

3.1 㖕剆

免震試験体における計測器の配置を、図 1 に示す。 主な計測項目は、振動台と重量部の加速度、速度、免 震層の水平、鉛直変位である。以下の測定器を使用し た。

a)加速度計 : ひずみゲージ型加速度計

b)速度計 : サーボ型速度計

c)変位計 : 非接触型変位計、リニア型パルスカウント 式変位計、ポテンショメータ型変位計
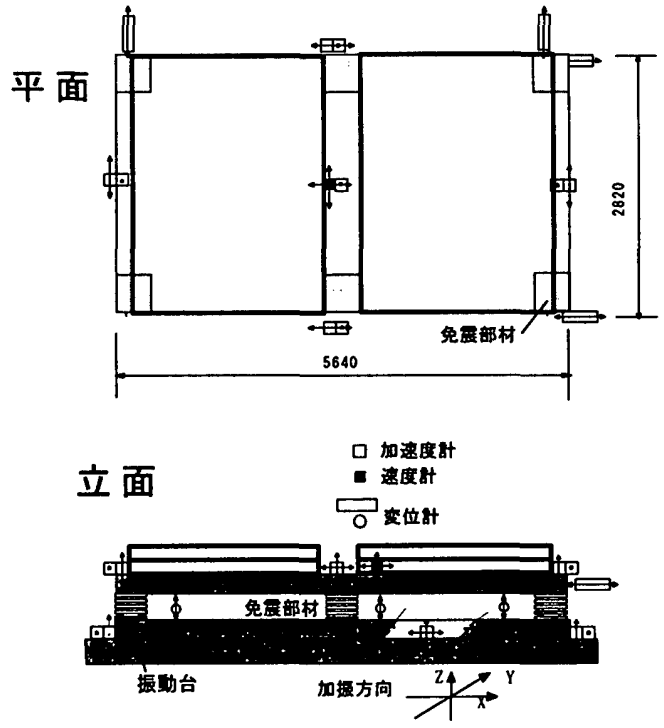

図 1 免震試験体の概要

(

\section{2 加振}

既往の観測地震動を振動台から入力した。採用した観測地震動は、 $1940 \mathrm{El}$ Centro、1995 神戸海洋気象台の加速度記録である。地震動の 大きさは、各地震動の 3 成分(NS、EW、UD)の内、最大速度となる 成分の速度の最大值を $25 、 50 \mathrm{~cm} / \mathrm{s}$ となるように調整し、その係数を すべての成分の振幅に乗じている。ただし部材 T においては $1940 \mathrm{El}$ Centro 地震動の最大速度を $40 \mathrm{~cm} / \mathrm{s}$ とした。これは、1940 El Centro

表 1 振動台からの入力地震動の各成分の最大速度例

\begin{tabular}{|c|c|c|c|c|c|c|c|}
\hline \multirow{2}{*}{\multicolumn{2}{|c|}{$\frac{\text { 地震動名 }}{\text { 方向 }}$}} & \multicolumn{3}{|c|}{1940 El Centro } & \multicolumn{3}{|c|}{1995 神戸海洋気象台 } \\
\hline & & $\mathrm{X}$ & $\mathrm{Y}$ & $\mathrm{Z}$ & $\mathrm{X}$ & $\mathrm{Y}$ & $\mathrm{Z}$ \\
\hline 最大速度 & 25 & 24.8 & 20.4 & 6.32 & 23.1 & 23.9 & 12.4 \\
\hline$(\mathrm{cm} / \mathrm{s})$ & 50 & 49.1 & 39.7 & 12.2 & 44.6 & 48.3 & 23.1 \\
\hline
\end{tabular}

表 2 加振の次元数とその記号

\begin{tabular}{|c|c|c|c|}
\hline 加振次元と記号 & $\begin{array}{c}\mathrm{X} \text { 方向 } \\
\text { (EW成分) }\end{array}$ & $\begin{array}{c}\mathrm{Y} \text { 方向 } \\
\text { (NS成分) }\end{array}$ & $\begin{array}{c}\text { Z 方向 } \\
\text { (UD成分) }\end{array}$ \\
\hline 1 方向 $(\mathrm{X})$ & $\bigcirc$ & & \\
\hline 1 方向 $(\mathrm{Y})$ & & $\bigcirc$ & \\
\hline 2 方向 $(\mathrm{XY})$ & $\bigcirc$ & $\bigcirc$ & \\
\hline 2 方向 $(\mathrm{YZ})$ & & $\bigcirc$ & $\bigcirc$ \\
\hline 3 方向 $(\mathrm{XYZ})$ & $\bigcirc$ & $\bigcirc$ & $\bigcirc$ \\
\hline
\end{tabular}

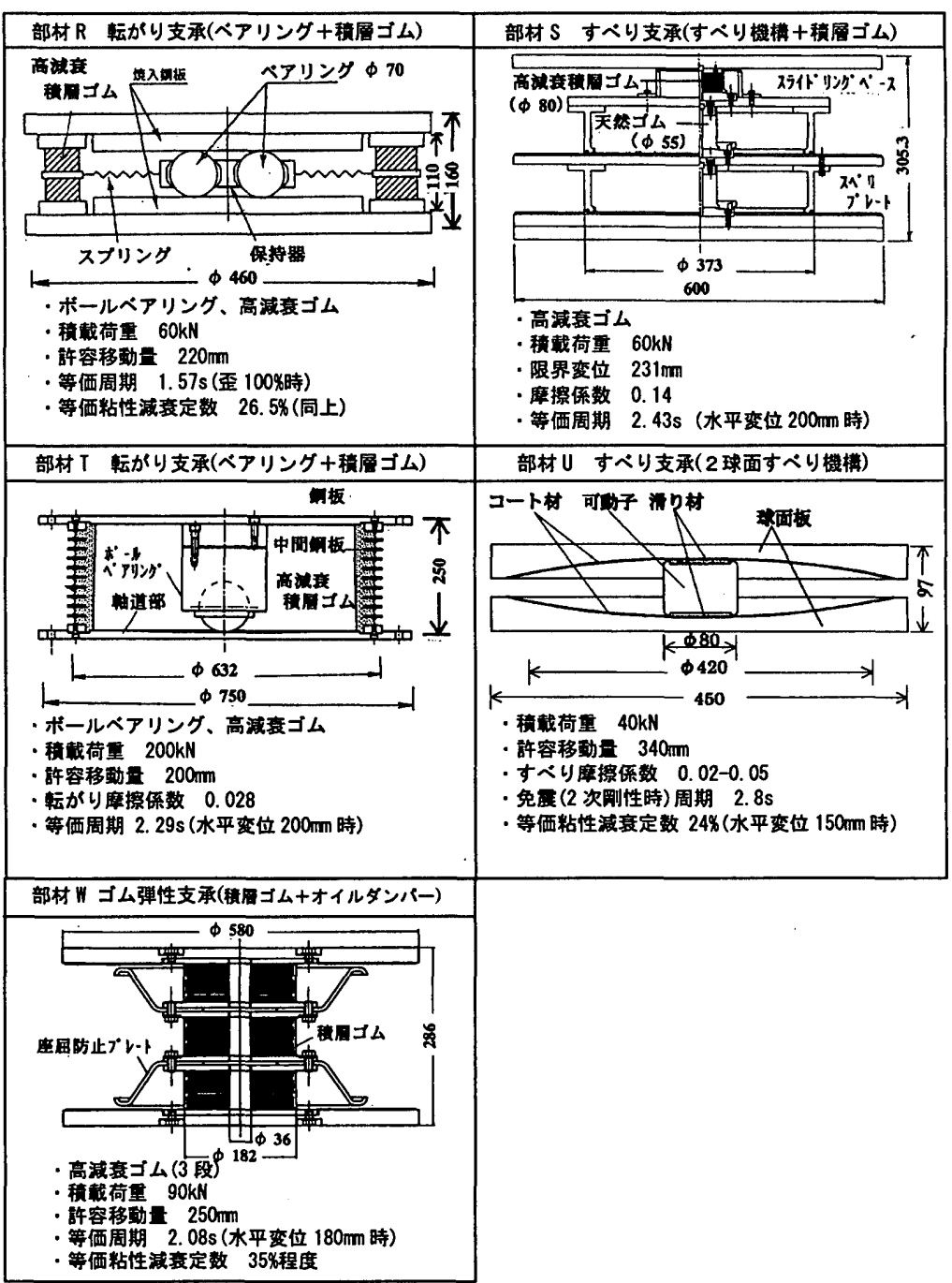

図 2 実験に用いた免震部材 
$50 \mathrm{~cm} / \mathrm{s}$ の 2 方向入力の際、部材の変 形が限界值に達したことから、最大 速度を小さくして実験を行ったため である。地震動の各方向における最 大速度の例を表 1 に示す。振動台の X、 $\mathrm{Y} 、 \mathrm{Z}$ 方向はそれぞれ地震動の $\mathrm{EW、}$ NS、UD 成分に対忘する。

表2に、免震試験体に入力した地震 動の成分の組み合わせを示す。。基本 的には、XまたはY各 1 方向加振 $(X$ 加 振、Y加振)、水平 2 方向加振(XY加振)、 3 方向加振 $(X Y Z$ 加掁)である。またい くつかの部材については、鉛直動の 影響を確認するために、鉛直動のみ 加速度振幅を 2 倍に増幅した 3 方向 加振 $(X Y Z 2$ 加振)も行った。

\section{3 データ処理}

計測された加速度波形に関してはローパスフィルタ一処理を行っ た。加速度波形をフーリエ変換し、その振幅に振動数 $15 \mathrm{~Hz}$ から $20 \mathrm{~Hz}$ にかけて線形に減少する関数 $(15 \mathrm{~Hz}$ で $1.0 、 20 \mathrm{~Hz}$ で 0.0)を乗じた後、 逆フーリエ変換し、波形に戻している。速度、変位データに関して は、ローパスフィルター処理を行っていない。

\section{2 方向・3方向加振による免震層のせん断力係数と水平变位の} 応答特性

水平 2 方向地震動および鉛直動の免震層の応答特性への影響を検 討するために、 1 方向( $\mathrm{X}$ または $\mathrm{Y}$ 加振)、 2 方向加振および 3 方向 加振における免震層の水平変位(振動台との相対変位)の軌跡および せん断力係数一水平変位の関係を比較する。なお、免震層のせん断 力係数は、免震試験体の中央に取り付けた水平加速度計の值を重力 加速度で除して求めている。また、免震層の水平変位は、各方向で 2 カ所に取り付けた変位計の值の平均值である(図 1 参照)。

以下、部材 T、UおよびWにおける実験結果を示す。機構の特性 が似ている部材が複数存在する場合には、免震部材の機構がより一 般的と考えられる部材の結果を示すこととした。なお、部材 $\mathrm{R}$ と $\mathrm{S}$ の実験結果を付録に示す。

図3に、部材 T、UおよびWにおける免震層の水平変位の軌跡(1995 神戸海洋気象台 $50 \mathrm{~cm} / \mathrm{s}$ 入力)を示す。図中、X+Y の凡例で示した結 果は、 $\mathrm{X}$ 加振による $\mathrm{X}$ 方向変位、Y 加振による $\mathrm{Y}$ 方向変位をそれぞ れ $\mathrm{X}$ 座標、 $\mathrm{Y}$ 座標の值として、同一平面に描いた結果である。 $\mathrm{XY}$ 加振における軌跡と X加振と Y 加振の結果を重ね合わせた軌跡を比 較すると、軌跡性状に差が生じており、特に部材 Uで差が大きい。 $\mathrm{XY}$ 加振と XYZ 加振による水平变位の軌跡においては、部材 U でわ ずかに差が見られるものの、その差は小さく、鉛直動の免震層の水 平変位に及ぼす影響は小さい。

図 4 に、1940 El Centro $50 \mathrm{~cm} / \mathrm{s}$ 入力に対する部材 U と W における 免震層の水平変位の軌跡を示す。部材 $\mathrm{W}$ における加振次元数による 差は小さいのに対し、部材 U では、XY 加振における軌跡は、X 加 振と $\mathrm{Y}$ 加振の結果を重和合わせた軌跡に比べて、水平変位が大きく なる結果が得られた。
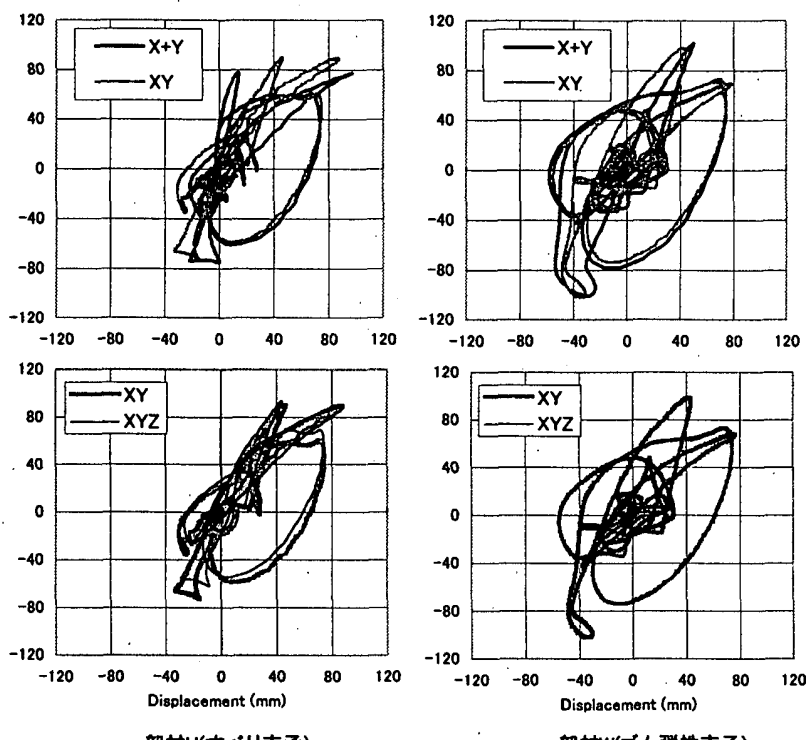

部材U(すべリ支承)

部材W(ゴム弾性支承)
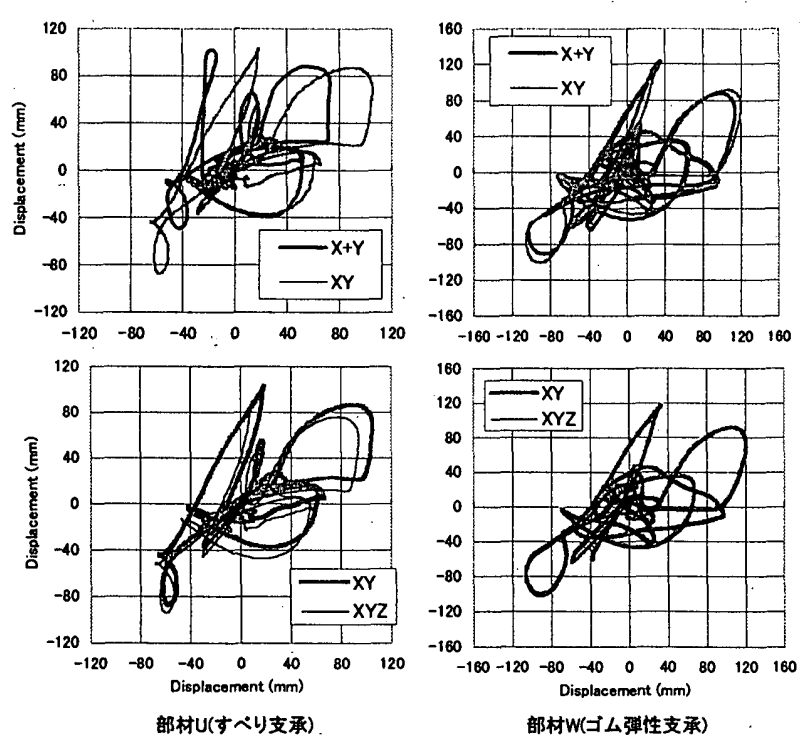

図 4 部材 U と W における水平変位の軌跡(1940 El Centro 50 $\mathrm{cm} / \mathrm{s}$ )

図 5 に、部材 $\mathrm{T} 、 U$ およびWにおける、Y 方向の免震層のせん断 力保数一水平变位の関係を加振次元数別に比較した(1995 神戸海洋 気象台 $50 \mathrm{~cm} / \mathrm{s}$ 入力)。部材 $\mathrm{T}$ と W では、 $\mathrm{Y}$ 加振と $\mathrm{XY}$ 加掁における 結果には顕著な差は見られないが、部材 U では、Y 方向の関係に直 交方向の变位の影響が見られる。XYZ 加振の場合、免震層のせん断 力係数に短周期成分の忘答が含まれてくる。図 6 に、XYZ2 加振に おける Y 方向の免震層のせん断力係数一水平变位の関係を示す。免 震層のせん断力係数に短周期成分の影響がより顕著に見られるが、 層せん断力保数一水平変位の履歴特性は、Y 加振における関係(図 5 参照)から大きくは変化しない。

図 7 に、1940 El Centro $50 \mathrm{~cm} / \mathrm{s}$ 入力に対する、部材 U と W におけ るX方向の免震層のせん断力係数一水平変位の関係を加振次元数別 に比較した。XY 加振の場合、部材 Uの免震層のせん断力係数一水 平変位の関係には、 2 方向入力の影響が見られ、バイリニアの関係 がやや崩れる特性を示す。1995神戸海洋気象台入力(図 5)に比べて、 $1940 \mathrm{El}$ Centro 入力における層せん断力係数には短周期成分が多く 
見られる。これは第 7章に示すように、免 震層の水平加速度応答が鉛直動の影響を 受けるためである。

\section{2 方向加振による免震層の最大応答値}

兔震層の最大応答値に及ほす水平 2 方 向地震動および鈆直動の影響を検討する ために、加振次元数の違いによる最大応答 值を比較する。表 3 に示す応答値を比較の 対象とする。

図 8 に、1995 神戸海洋気象台 25 または $50 \mathrm{~cm} / \mathrm{s}$ 入力における、 1 方向加振に対す る 2 方向加振の $\mathrm{X}$ あるいは $\mathrm{Y}$ 方向の最大 水平加速度の比 $(\alpha \mathbf{x}, \mathbf{x y} / \alpha \mathbf{x}, \mathbf{x} 、 \alpha \mathbf{y}, \mathbf{x y} / \alpha$ $\mathrm{y}, \mathrm{y})$ および最大水平変位の比 $(\delta \mathrm{x}, \mathrm{xy} / \delta \mathrm{x}, \mathrm{x}$ 、 $\delta \mathrm{y}, \mathrm{xy} / \delta \mathrm{y}, \mathrm{y})$ を示す。最大水平加速度の場 合、比の值は $0.8 \sim 1.12$ の範囲にある。最 大変位の場合、0.85 1.43 となる。部材 $R$ 、 TおよびWにおける最大変位の比は 0.9 1.0 の範囲にある。これは図 5 に示す免震 層のせん断力係数一水平変位の関係にお いて、 1 方向加振と 2 方向加振結果の差が 小さいことに対応している。すべり支承( U)では、 2 方向加振における最大值の方が 大きくなる場合が見られ、最大水平変位の 比のばらつきが大きい。

1940 El Centro 入力における同様の結 果を図 9 に示す。図 8 に示した結果と同様 の傾向を示すものの、部材 $\mathrm{R} 、 \mathrm{~T}$ および $\mathrm{W}$ での最大水平変位の比は $1.0 \sim 1.1$ 程度と なる。また、部材 $\mathrm{S}$ と Uでは、最大水平 変位の比の值のばらつきが大きくなり、2 方向加振の影響を大きく 受ける結果が得られた。

上に示した水平変位の最大值は、各加振前の免震部材の位置から の水平変位の最大值(絶対值による算定)である。加振後の免震部材 には残留変位が発生するため、本来加振後には免震部材の残留応 カ・残留変位を解除して、次の加振を行うことが望ましい。しかし、 本実験では時間の制約から、免震部材の残留応力・残留変位を残し たままの状態で次の加振を行ったため、免震部材に初期変位が存在

表 3 最大水平応答値比較のための記号と定義

\begin{tabular}{|c|c|}
\hline 最大応答值の記号 & 説明 \\
\hline & $\begin{array}{l}\text { XあるいはY加振における同方向の免罢層の最大水平加 } \\
\text { 速度または最大水平変位 }\end{array}$ \\
\hline $\begin{array}{l}\alpha \mathrm{t}, \mathrm{x}+\mathrm{y} \text { または } \\
\delta \mathrm{t}, \mathrm{x}+\mathrm{y}\end{array}$ & $\begin{array}{l}\mathrm{X} \text { 加振、Y 加振における各時刻でのそれぞれの方向の水 } \\
\text { 平加速度または平平変位の } 2 \text { 乗和平方根の最大值。 }\end{array}$ \\
\hline $\begin{array}{l}\alpha \mathrm{m}, \mathrm{x}+\mathrm{y} \text { または } \\
\delta \mathrm{m}, \mathrm{x}+\mathrm{y}\end{array}$ & $\begin{array}{l}\mathrm{X} \text { 加振、 } \mathrm{Y} \text { 加振におけるそれぞれの方向の免震層の最大 } \\
\text { 水平加速度 }(\alpha \mathrm{x}, \mathrm{x} 、 \alpha \mathrm{y}, \mathrm{y}) \text { ) } 2 \text { 乗和平方根または最大水平 } \\
\text { 変位 }(\delta \mathrm{x}, \mathrm{x} 、 \delta \mathrm{y}, \mathrm{y}) \text { の } 2 \text { 乗和平方根値。 }\end{array}$ \\
\hline $\begin{array}{l}\alpha \mathrm{x}, \mathrm{xy}, \quad \alpha \mathrm{y}, \mathrm{xy} \text { ま } \\
\text { たは } \delta \mathrm{x}, \mathrm{xy}, \delta \mathrm{y}, \mathrm{xy}\end{array}$ & $\begin{array}{l}\mathrm{XY} \text { 加振における } \mathrm{X} \text { 方向、Y 方向の免䠆層の最大水平加 } \\
\text { 速度または最大水平変位。 }\end{array}$ \\
\hline$\alpha \mathrm{t}, \mathrm{xy}$ または $\delta \mathrm{t}, \mathrm{xy}$ & $\begin{array}{l}\mathrm{XY} \text { 加振における X 方向、Y 方向の各時刻での免祳層の } \\
\text { 水平加速度または水平变位の } 2 \text { 乗和平方根の最大值。 }\end{array}$ \\
\hline $\begin{array}{l}\alpha \mathrm{t}, \mathrm{xyz} \text { または } \\
\delta \mathrm{t}, \mathrm{xyz}\end{array}$ & $\begin{array}{l}\mathrm{XYZ} \text { 加振における X 方向、Y 方向の各時刻での免䁾層 } \\
\text { の水平加速度または水平変位の } 2 \text { 乗和平方根の最大值。 }\end{array}$ \\
\hline
\end{tabular}
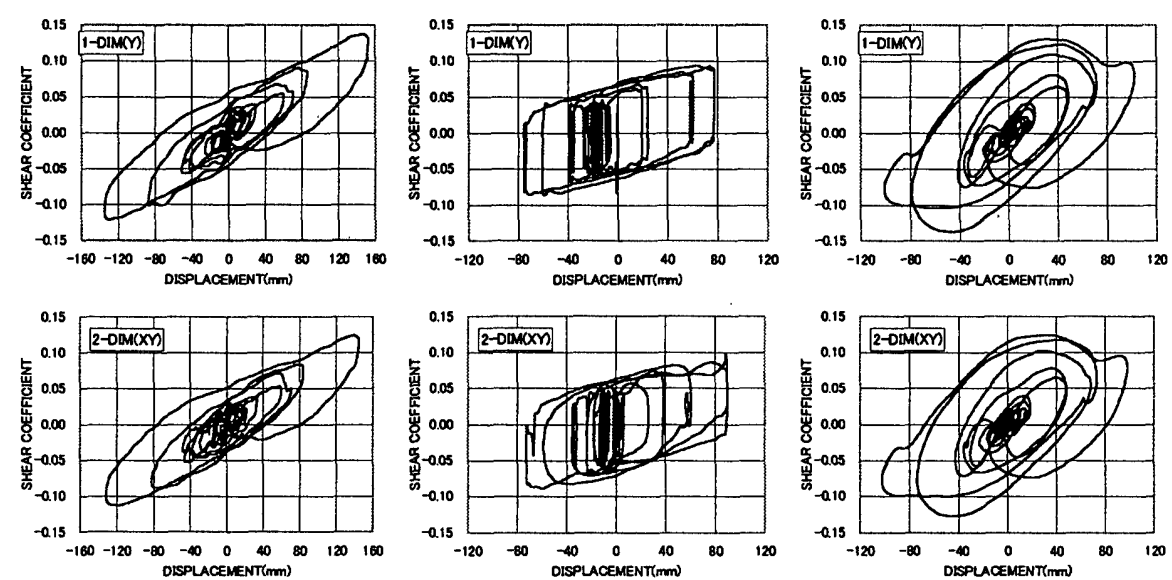

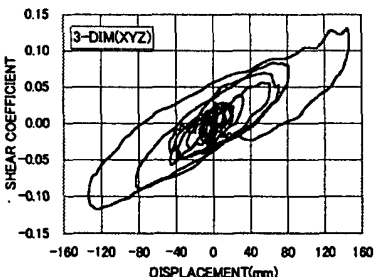

部材T(転がり支承)

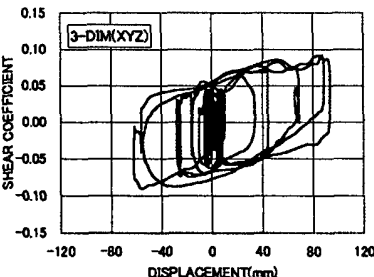

部材U(すべり支承)

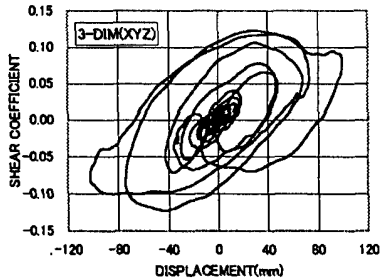

部材W(ゴム弾性支承)
図 5 地震動の加振次元数の違いによる Y 方向の免震層のせん断力係数一水平変位の関係 (1995 神戸海洋気象台 $50 \mathrm{~cm} / \mathrm{s}$ )

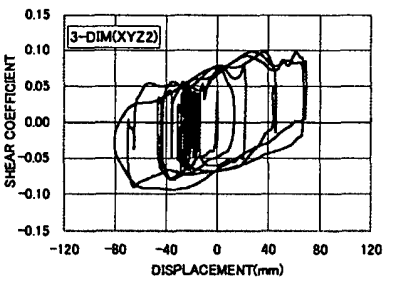

部材U(すべり支承)

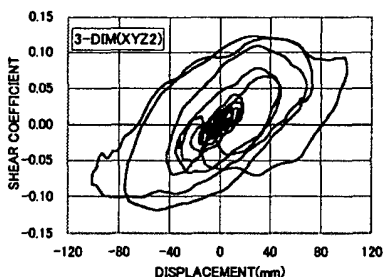

部材W(ゴム弾性支承)
図 6 鉛直動のみ振幅を 2 倍にした場合の $\mathrm{Y}$ 方向の免震層のせん断力係数一水平变位の関俰 (1995 神戸海洋気象台 $50 \mathrm{~cm} / \mathrm{s}$ )
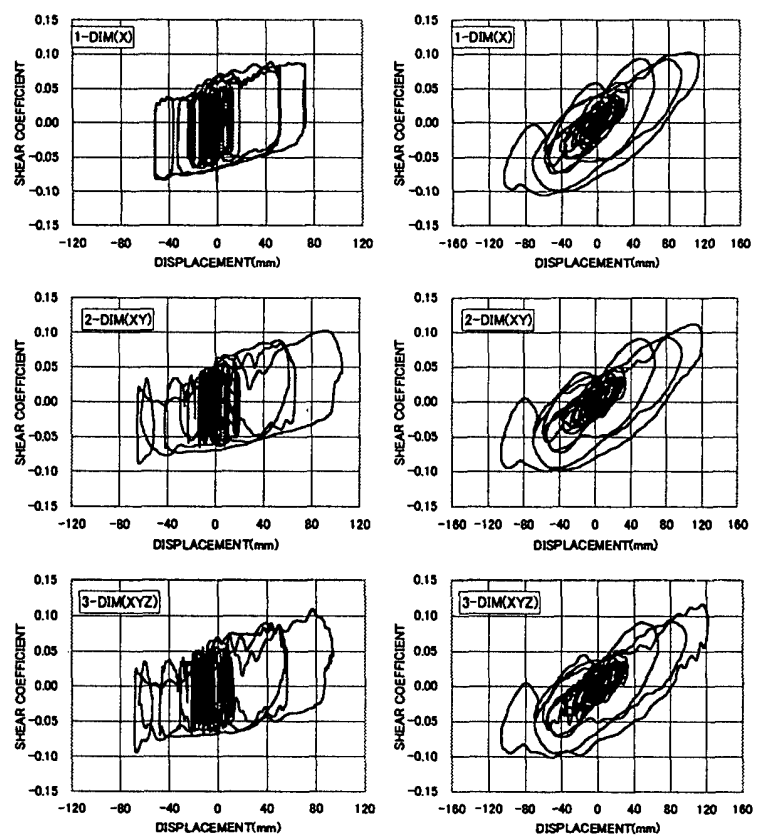

部材U(すべり支承)

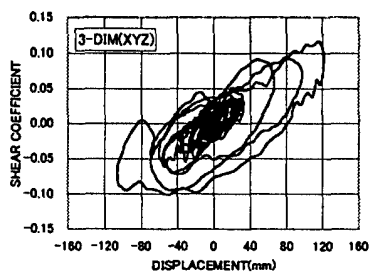

部材W(ゴム彈性支承)

図 $7 \mathrm{X}$ 方向の免震層のせん断力俰数一水平変位の関保 (1940 El Centro $50 \mathrm{~cm} / \mathrm{s}$ ) 

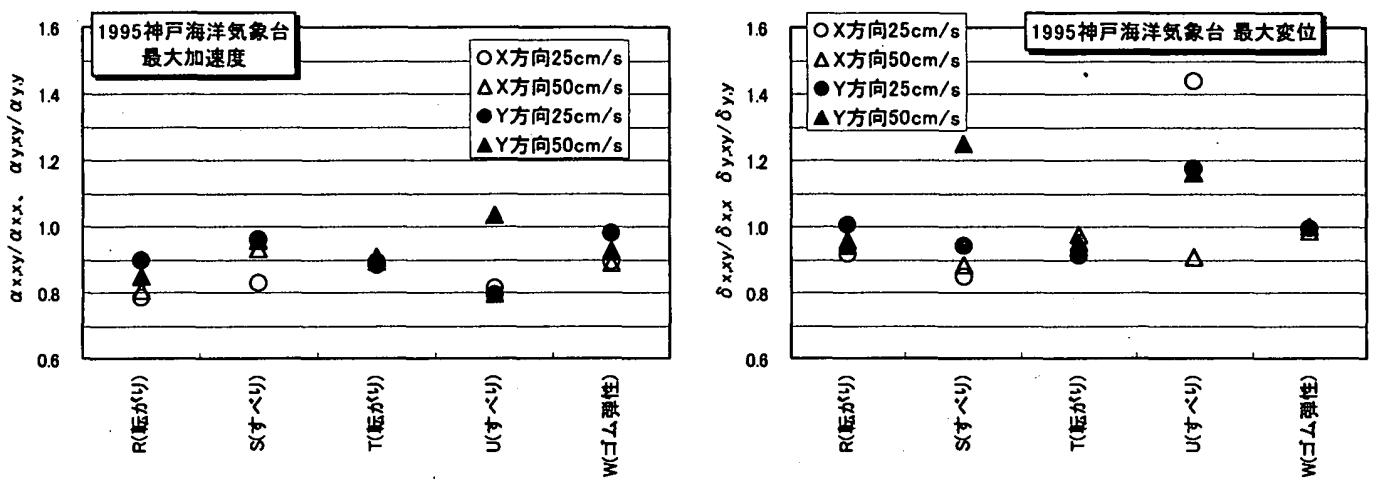

図 8 各方向の免震層の最大水平加速度、最大水平变位における 1 方向加振結果に対する 2 方向加振結果の比(1995 神戸海洋気象台)
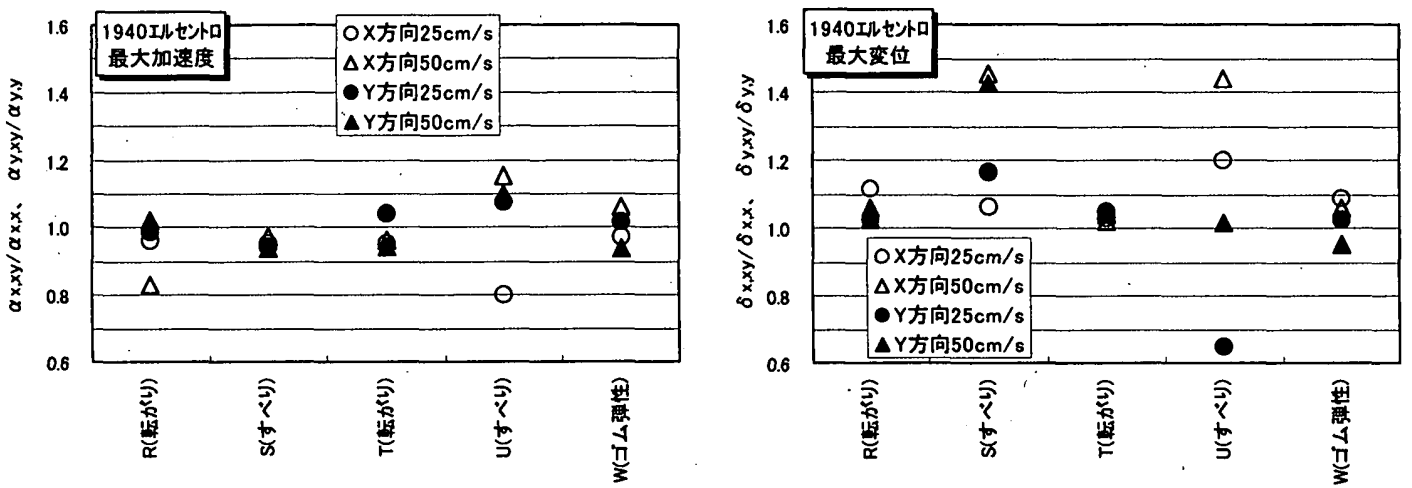

図 9 各方向の免震層の最大水平加速度、最大水平変位における 1 方向加振結果に対する 2 方向加振結果の比(1940 El Centro)

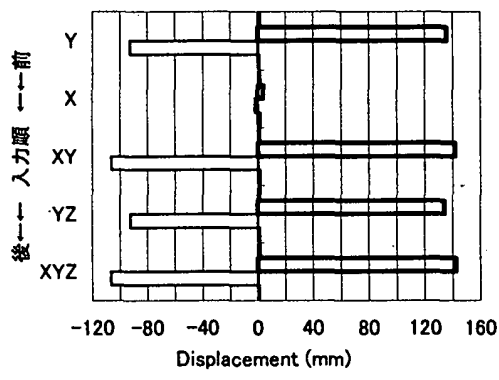

a) 部材 $T($ 転がり)

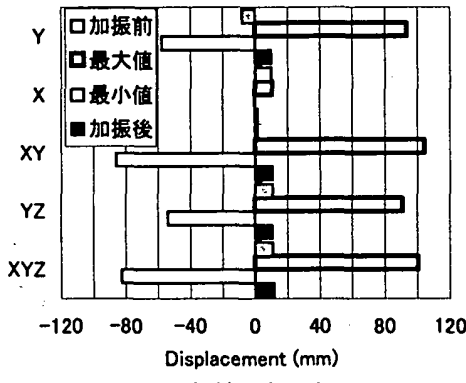

b) 部材U(すべり)

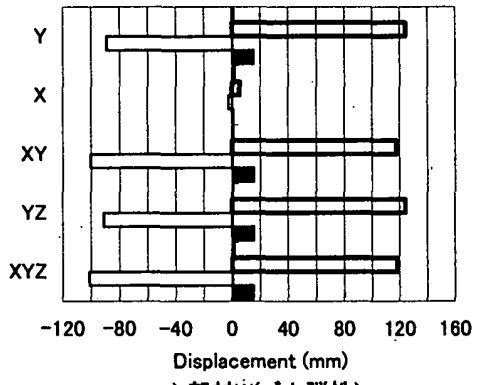

c) 部材W(ゴム弾性)

図 $10 \mathrm{Y}$ 方向の免震層の水平变位の推移 $(1940 \mathrm{El}$ Centro $50 \mathrm{~cm} / \mathrm{s})$

する条件となっている。図 10 には、1940 El Centro $50 \mathrm{~cm} / \mathrm{s}$ 入力における、Y 方向の免震層の 水平変位の加振前、最大(正側)、最小、加振後 の值を加振の時系列で示した。部材 $\Upsilon$ に、ほ とんど残留変位が発生していない。また部材 $\mathrm{W}$ では、 $15 \mathrm{~mm}$ 程度の残留変位を発生するが、次 の加振までに残留変位が非常に小さくなる。一 方部材 U の場合、 $10 \mathrm{~mm}$ を越える残留変位が発 生するが、同一の振幅の地震動を繂り返すと加 振前後での水平変位がほぼ等しくなる。部材 $\mathrm{S}$ の場合、免震部材の 2 次剛性が非常に小さいた め、残留変位の最大値は $25 \mathrm{~mm}$ 程度となった。

免震部材の残留変位の影響を除くために、Y 方向の免震層の水平 変位の両振幅での最大値(最大値(正側)と最小値の差)を算定し、1方 向加振に対する 2 方向加振の最大水平変位の比を図 11 に示す。1995
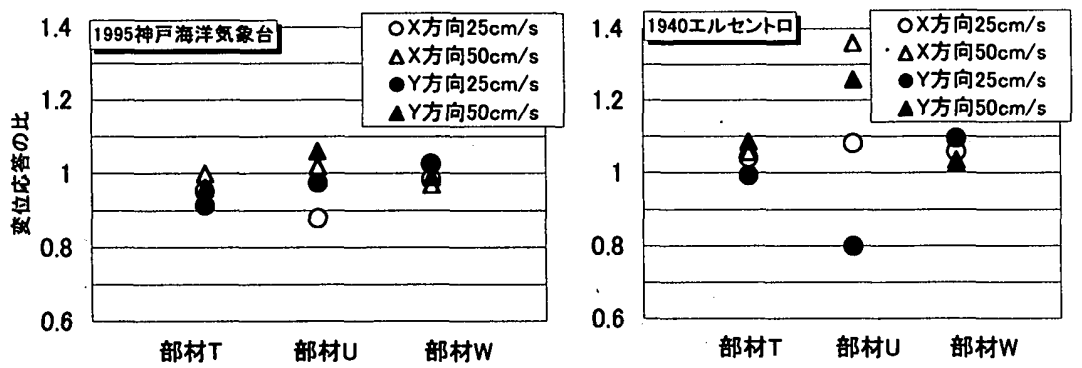

図 11 両振幅最大水平変位における 1 方向加振結果に対する 2 方向加振結果の比

神戸海洋気象台入力の場合、図 8 に示寸値に比べて、部材Uでばら つきが小さくなる。一方 1940 El Centro 入力の場合、比の值のばら つきの幅はやや小さくなるものの、 2 方向加振における最大水平変 位の方が大きくなる性状は変わらないことが明らかとなった。以下 の検郡では、加振前の免震部材の位置からの相対変位を免震層の水 

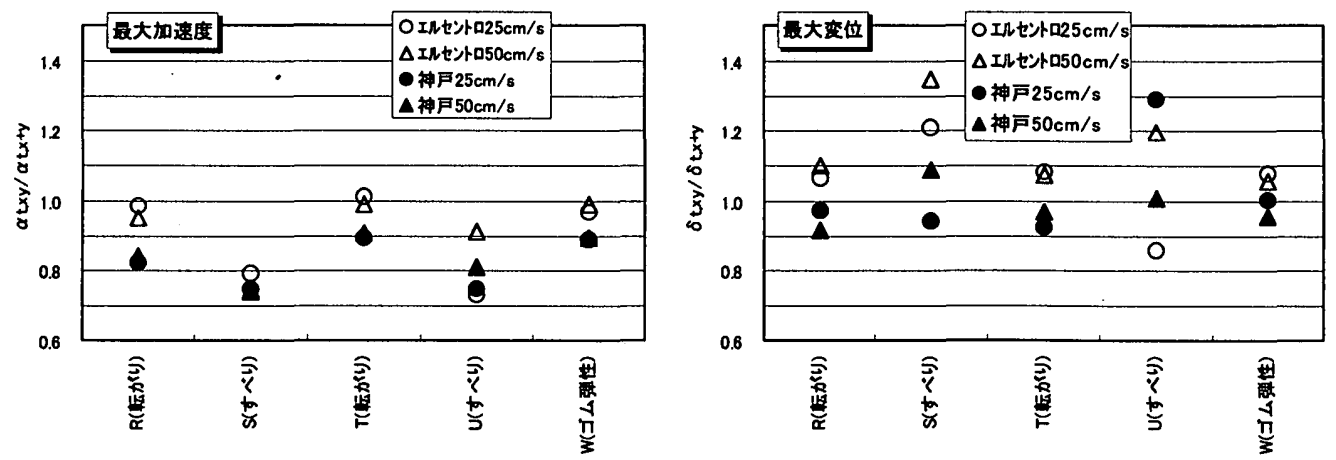

図 12 免震層の最大水平加速度、最大水平变位の 1 方向加振合成最大值に対する 2 方向加振合成最大值の比

平变位とし、その最大值を用いて検討することとする。

図 12 に、X または $\mathrm{Y}$ 加振における応答の各時刻における 2 乗和 平方根の最大值( 1 方向加振の合成最大值)に対する 2 方向加振にお ける X と Y 方向の 2 乗和平方根の最大値( 2 方向加振の合成最大値) の比 $(\alpha \mathrm{t}, \mathrm{xy} / \alpha \mathrm{t}, \mathrm{x}+\mathrm{y} 、 \delta \mathrm{t}, \mathrm{xy} / \delta \mathrm{t}, \mathrm{x}+\mathrm{y})$ を示す。1940 El Centro 地祳動に おいて、最大水平加速度の比が大きくなるが、比の值はほほ 1.0 以 下の値である。1 方向加振の合成最大値は、2 方向加振の合成最大 值のほほ上限の值を与えることがわかる。一方最大水平变位におい ては、転がり支承やゴム弾性支承の場合、1995 神戸海洋気象台地震 動で 0.9〜 1.0、1940 El Centro 地震動で 1.05〜 1.1 と比較的一定の値 を示す。一方、すべり支承では 1 を大き吅る場合が多く、2 方 向加振の合成最大值を 1 方向加振の合成最大值で算定すると過小評 価となる。

図 13 に、Xまたは $Y$ 加振における各方向の水平変位の最大值の 2 乗和平方根 (各方向の最大值の合成值)に対する 2 方向加振の合成 最大值の比 $(\delta \mathrm{t}, \mathrm{xy} / \delta \mathrm{m}, \mathrm{x}+\mathrm{y})$ を示す。すべり支承の一部の結果を除い て、2 方向加振の合成最大值を各方向の最大值の合成值を用いるこ とにより、免震層の最大水平変位を安全側に算定することができる。

\section{6. すべり支承の 2 方向加振時の免震層水平変位応答值の評価}

すべり支承において、1 方向加振に対する 2 方向加振結果の最大 水平変位の比が大きくなる原因について検討する。1940 El Centro $50 \mathrm{~cm} / \mathrm{s}$ 入力における、部材 U と W の水平変位の軌跡(最大応答が生 じる時刻付近の結果)を図 14 に示す。部材 U の場合、1 方向加振の 重ね合わせによる水平変位より、 2 方向加振の水平変位が大きくな る。特に X、Y 方向に同程度の水平変位が同時に発生する場合に、 水平変位の変化量が増大する。このような変位軌跡を生じると、 $\mathrm{X} 、$

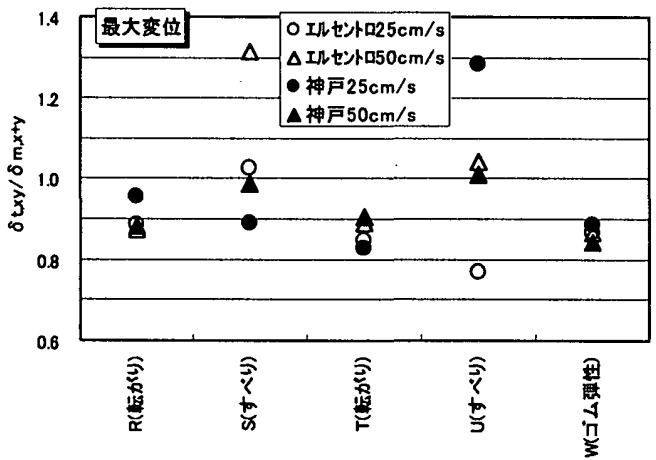

図 13 免震層の最大水平変位の 1 方向加振における最大值合成値 に対する 2 方向加振における合成最大值の比較
$\mathrm{Y}$ 各方向の水平変位の 2 乗和平方根では 2 方向加振の水平変位を過 小に評価することになる。一方、部材 $\mathrm{W}$ の場合は 2 方向加振の水平 変位が大きくなるが、その程度は小さい。部材 Uの場合、図 5 に示 す層せん断力係数一水平变位の特性が加振次元に関俰なく安定して おり、2 方向の降伏耐力の相関関俰が円形であるためと考えられる。 部材 $\mathrm{T}$ と $\mathrm{W}$ の場合、免震層の応答速度が大きくなると、層せん断 力係数が大きくなる特性を示すことから、2 方向の降伏耐力の相関 関係が少なくなるため、1 方向と 2 方向加振の差が部材 U ほど大き くならなかったと考えられる。

次に、2 方向地震動における水平変位応答を主軸方向の地震動を 用いた応答解析により検討する。ここでは、主軸方向を XY 平面で 免震層の水平変位が最大となる方向とする ${ }^{11)}$ 。図 15 のように、部 材 U の履歴特性をバイリニアにモデル化する。降伏層せん断力保数 や 2 次剛性は、1995 神戸海洋気象台 $50 \mathrm{~cm} / \mathrm{s}$ の Y 加振時の実験結果 から求めた。

表 4 に、1995 神戸海洋気象台および 1940 El Centro $50 \mathrm{~cm} / \mathrm{s}$ 入力に おける 2 方向加振時の免震層の最大水平変位を示す。地震応答解析 の場合、 X、Y 方向および主軸方向の地震動に対する結果を示す。
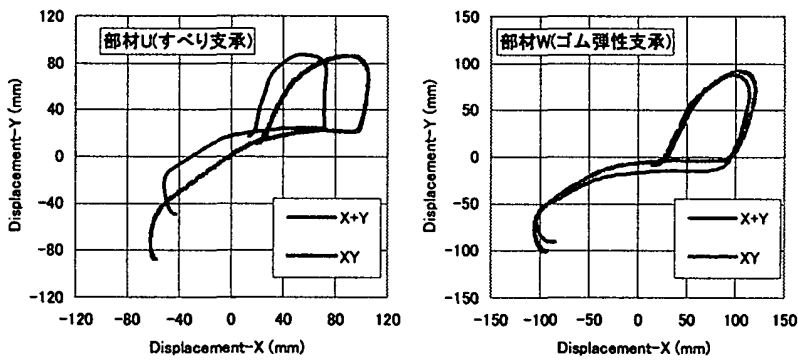

図 14 部材 U と W におおる免震層水平変位の軌跡 (最大水平変位発生時刻付近、1940 El Centro $50 \mathrm{~cm} / \mathrm{s}$ )

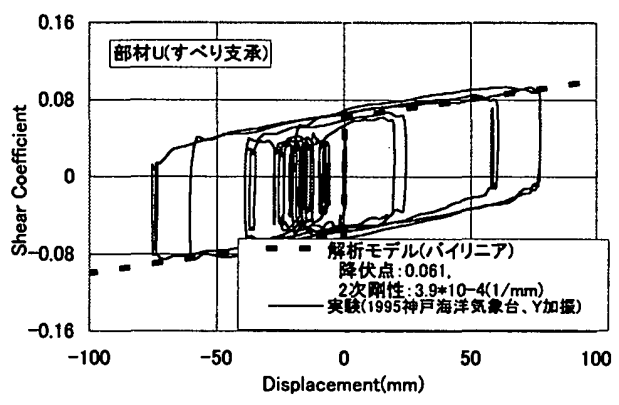

図 15 部材 Uの層せん断力保数一水平変位の解析モデル 
主軸の X 軸に対する角度は、1995 神戸海洋気象台および $1940 \mathrm{El}$ Centro 地震動で、それぞれ 45.6、39.2 度である。また図 16 に、1940 El Centro入力時の免震層の主軸方向のせん断力係数一水平変位の関 係を示す。主軸方向の地震動を用いた解析結果は実験結果と良い対 态を示し、バイリニア特性を有するすべり支承の 2 方向地震動にお ける水平変位の算定には、主軸方向での応答計算が非常に良い精度 の結果を与えることが確談できた。

図 12 において、1 方向加振の重就合わせの最大水平変位と 2 方 向加振の最大值を比較すると、一部の結果を除いて、1995 神戸海洋 気象台入力ではほぼ等しく、1940 El Centro 入力では 2 方向加振の結 果が大きくなる。この理由として最大水平変位の発生する水平面て の位置が関倸していると考えられる。 $\mathrm{X}$ と $\mathrm{Y}$ 方向に、同程度の水平 変位が同時に生じる場合、1 方向加振に比べて水平変位が大きくな り、1940 El Centro 入力における最大水平変位発生時の主軸方向はほ ほ 45 度方向となり(図 4 参照)、特にすべり支承にその影響が大きく 見られた。一方、1995 神戸海洋気象台入力の場合、最大水平変位の 発生時の主軸方向は $\mathrm{Y}$ 軸に近いため、1 方向と 2 方向加振の差が小 さかったと考えられる(図 3 参照)。

\section{7. 免震層応答への鉛直動の影響}

\section{1 免震試験体の鉛直方向の応答特性}

まず 3 方向加振(最大速度 $50 \mathrm{~cm} / \mathrm{s}$ )における免震試験体の鉛直方向 の特性について示す。図 17 に、各地震動の鉛直成分のフーリエスペ クトルを示す。フーリエスペクトルには、5回のハニングウィンド ウ処理を行った。1995 神戸海洋気象台の場合、低振動数域の成分が 多いのに対し、1940 El Centro では、8〜13Hzの成分が多い。両地震 とも $13 \mathrm{~Hz}$ より高振動数域での成分は少なくなる。

表 5 に、3 方向加振における各免震部材の振動台の最大鉛直加速 度に対する免震層の最大鉛直加速度の増幅率を示す。免震層の鉛直 加速度は、免震試験体の周辺の 4 力所の加速度計の平均值である。 1995 神戸海洋気象台入力の場合、増幅率は比較的小さいのに対し、

表 4 免震層水平変位の地震応答解析結果

\begin{tabular}{|c|c|c|c|c|}
\hline \multirow{3}{*}{ 方向 } & \multicolumn{4}{|c|}{ 水平变位 $(\mathrm{mm})$} \\
\hline & \multicolumn{2}{|c|}{$\begin{array}{c}1995 \text { 神户海洋妾象台 } \\
50 \mathrm{~cm} / \mathrm{s}\end{array}$} & \multicolumn{2}{|c|}{$\begin{array}{l}1940 \text { El Centro } \\
50 \mathrm{~cm} / \mathrm{s}\end{array}$} \\
\hline & 実験 & 解析 & 実験 & 解析 \\
\hline X方向 & 89.7 & 89.9 & 103.4 & 53.8 \\
\hline $\mathrm{Y}$ 方向 & 89.9 & 90.6 & 105.2 & 104.4 \\
\hline ХとYの2乗和平方根 & \multirow{2}{*}{125.4} & 129.4 & \multirow{2}{*}{130.1} & 114.1 \\
\hline 主軸方向入力 & & 135.1 & & 134.4 \\
\hline
\end{tabular}

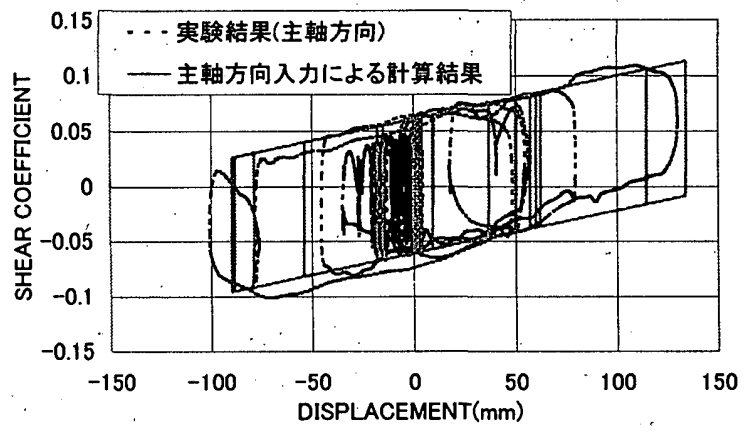

図 16 免震層のせん断力係数一水平変位の関係(主軸方向)
1940 El Centro 入力では、1.2〜2.9 倍の值を示す。特に、部材 T と W の增幅率が大きい。部材 T、U および W における振動台の鉛直加速 度に対する免震層の鉛直加速度のフーリエスペクトル比(ハニング ウィンドウ 5 回)を、図 18 に示す。免震試験体の鉛直方向の共振振 動数は、部材 $\mathrm{T}$ と W で 11〜12Hz、部材 U で約 $15 \mathrm{~Hz}$ である。1940 El Centro 入力で、部材 $\mathrm{T}$ と W の増幅率が大きくなった理由として、 免震層の鉛直方向の共振現象が関係している。

\section{2 鉛直動の免震層水平方向応答への影響}

3 方向加振(最大速度 $50 \mathrm{~cm} / \mathrm{s}$ )におうる、鉛直動の免震層の水平加 速度と水平変位への影響について述べる。

図 19 に、2 方向加振における合成最大值に対する 3 方向加振 (XYZ または XYZ2)における合成最大值の比を示す。最大水平加速 度の場合、比は 0.9 1.17 となり、鉛直動により比が増大する場合が 多い。一方、最大水平変位の比はほほ 0.87-1.01 の範冊にあり、鉛直 動が加わった場合の免震層の水平変位の最大值は、鉛直動がない場 合に比べて等しいか、むしろ小さくなる結果が得られた。

図 20 に、1940 El Centro 50 $\mathrm{cm} / \mathrm{s}$ 入力における、2 方向加振に対す る3方向加振の免震層の水平加速度( $\mathrm{Y}$ 方向)のフーリエスペクトル 比(ハニングウィンドウ 10 回)を示す。部材Uでは、振動数とともに、 スペクトル比が小さくなる傾向を示し、免震層の水平加速度には、 鉛直動の影響が見られない。一方、部材 W の場合、 $11 \mathrm{~Hz}$ 付近を中 心に比が大きくなる振動数域を有し、鉛直動が水平動の振動数特性

表 5 最大鉛直加速度の増幅率

\begin{tabular}{|c|c|c|}
\hline & 1995神戸海洋或象台 & 1940 El Centro \\
\hline 部材R(钽がり支承) & 1.01 & 1.18 \\
\hline 部材S(すべり支承) & 1.05 & 1.41 \\
\hline 部材 $\mathrm{T}$ (転がり支承) & 1.07 & 2.90 \\
\hline 部材U(すべり支承) & 1.09 & 1.20 \\
\hline 部材W(ゴム彈性支承) & 1.13 & 1.67 \\
\hline 平均 & 1.07 & 1.67 \\
\hline
\end{tabular}

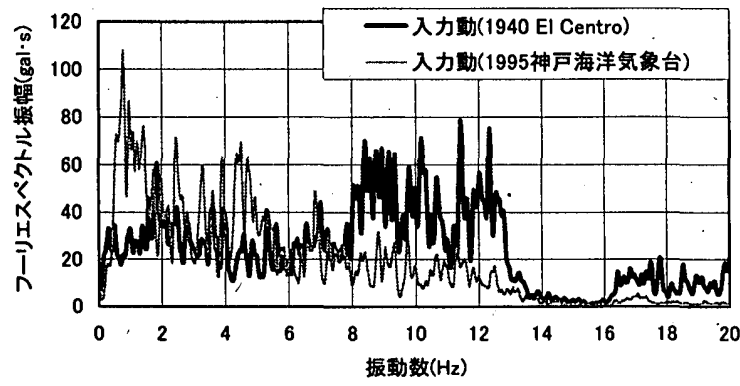

図 17 地震動の鉛直成分のフーリエスペクトル

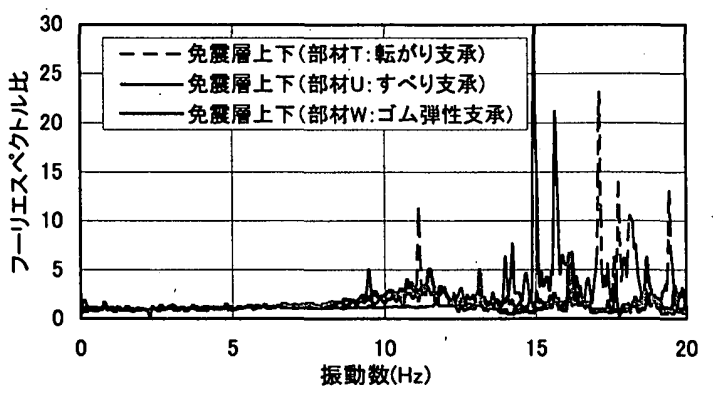

図 18 地震動の鉛直加速度応答のフーリエスペクトル比 $(1940 \mathrm{El} \mathrm{Centro50 \textrm {cm } / \mathrm { s } )}$ 

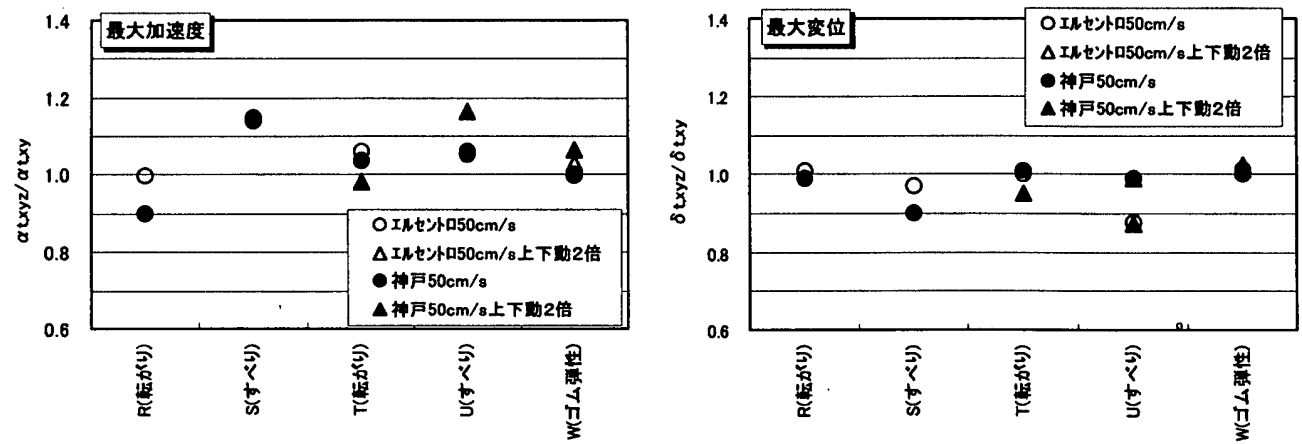

図 19 免震層の最大水平加速度、最大水平変位の 2 方向加振合成最大值に対する 3 方向加振合成最大值の比

に影響している。図 21 に、1940 El Centro 50 cm/s 入力 における、部材 U の免震層の水平加速度と鉛直加速 度の時刻歴を示す。 2 方向加振と 3 方向加振の免震層 の水平加速度を上図に、その差(鈆直動により付加さ れる水平加速度と考えられる)と免震層の鉛直加速度 を下図に描いた。免震層の水平加速度の差と鉛直加速 度が良く対応している時刻部分を○印で囲んだ。水平 加速度の変化が少ない時間帯には、鉛直加速度の影響 が顕著に見られる。この原因として、鉛直動によるす ベり支承の面圧の変動に伴うすべり摩擦力の変化が 生じていることが考えられる。図 22 には、同様に部 材 $\mathrm{W}$ の結果を示寸。部材 $\mathrm{W}$ の場合には、免震層の水 平加速度の差が鉛直加速度と良い対応を示しており、 免震層の水平加速度には、鉛直動の影響が含まれてい ることがわかる。その結果、部材 U と W ともに、鉛 直動により免震層の水平加速度が増加する。しかし、 その增加分の大きさは免震層の最大水平加速度に比 べてわずかであること、また水平加速度の成分が高振 動数であることから、鉛直動が免震層の水平変位に及 ぼす影響は小さいと判断される。

\section{8. まとめ}

機構の異なる免震部材を用いた免震試験体の 3 次 元振動台実験を行い、水平 1 方向、水平 2 方向、さら に鉛直動を含めた 3 方向地震動に対する免震試験体 の水平加速度や水平变位応答を求めた。免震層の最大 応答值や免震部材の力学特性に及ぼす水平 2 方向地 震動および鉛直動の影響についてまとめると以下の ようになる。

1)水平 2 方向地震動の免震層水平方向応答への影響

2 方向加振の場合、各方向の層せん断力係数一水平 変位の関係は、その直交方向の水平応答の影響を受け て、1方向加振の層せん断力保数一水平変位の関保と 差を生じる。その際、転がり支承やゴム弾性支承では 直交方向の影響は小さいのに対し、すべり支承では直 交方向の影響が大きい。1 方向加振結果を水平面に重㸚合わせて求 めた免震層の水平忘答と 2 方向加振における水平応答を比較すると、 以下のことが明らかになった。 a) 2 方向加振における水平面内での最大水平加速度 $(\mathrm{X}$ と $\mathrm{Y}$ 方向の各
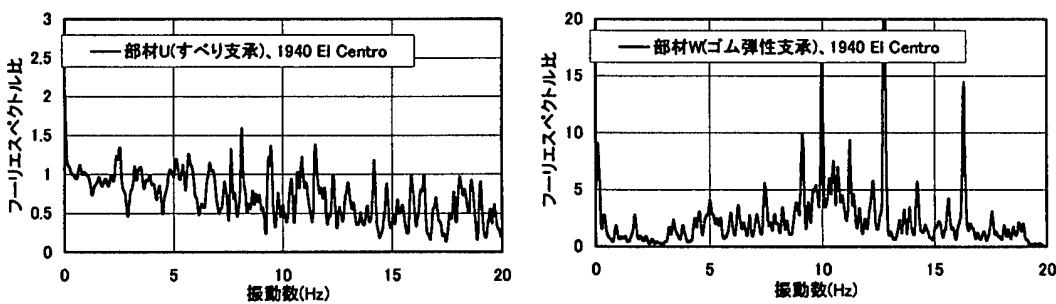

図 202 方向に対する 3 方向加振の免震層水平加速度応答のフーリエスペクトル比
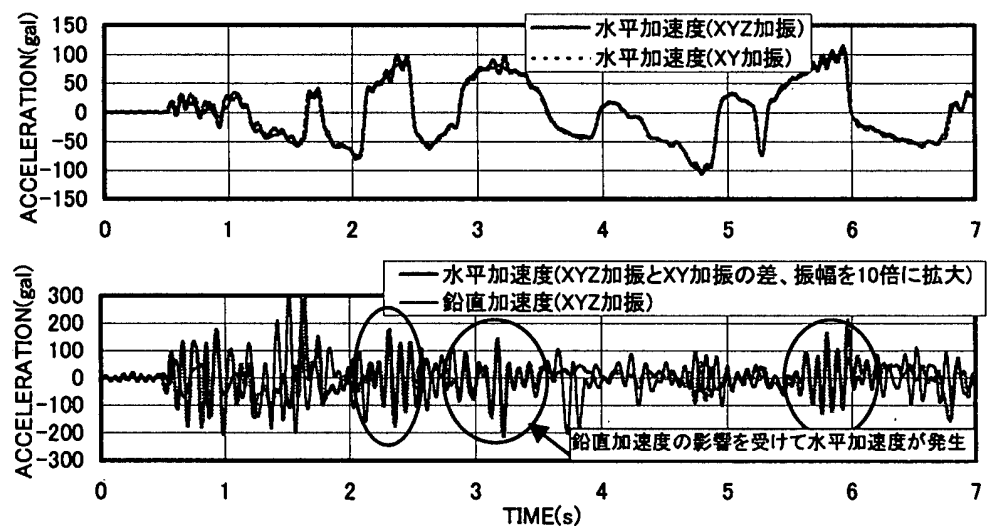

図 21 部材 U における免震層の水平加速度と鉛直加速度 $(1940 \mathrm{El}$ Centro50cm/s)
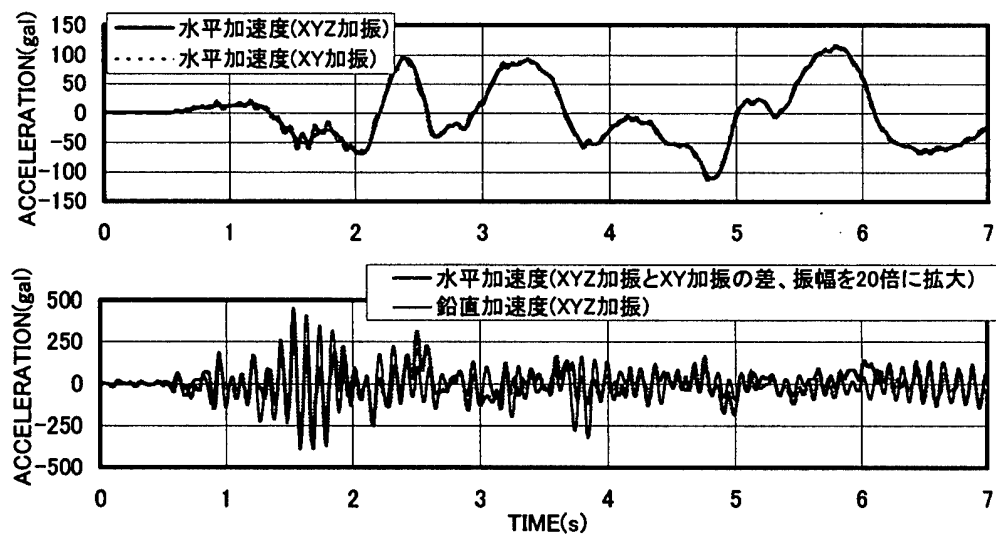

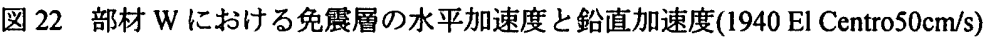

時刻での応答値の 2 乗和平方根の最大値)は、 1 方向加振の重ね合わ せた最大水平加速度と比べて同程度かやや小さくなる場合が多く、 1 方向加振における最大加速度は、 2 方向加振における最大值の上 限を与える。 
b) 2 方向加振における免震層の水平面の最大水平变位と 1 方向加振 の重ね合わせた最大水平变位を比較すると、1995 神戸海洋気象台地 震動では、雨者がほぼ等しい。一方、1940 El Centro 地震動では、2 方向加振における最大水平変位の方がやや大きい結果が得られた。 1 方向加振における各方向の最大値の 2 乗和平方根から求めた水平 変位を用いると、 2 方向加振における免震層の最大水平变位より大 きくなる場合が多く、兔震層の最大水平変位を安全側に評価できる。 ただし、すべり支承では、水平 2 方向の降伏耐力の相関関係が強い ため、この関保が成り立たない場合がある。

c) 1940 El Centro 地震動で、2 方向加振における免震層の最大水平変 位の方が大きくなる理由として、水平変位応答の主軸方向(最大水平 変位を発生する方向の軸)が関係していると考えられる。1940 El Centro 地震動における最大水平変位発生時の主軸方向はほほ 45 度 方向であり、Xと $\mathrm{Y}$ 方向に同程度の水平変位が同時に生じる場合に 水平変位が大きくなる。

d)すべり支承の場合、加振次元に関係なく、免震層のせん断力係数 一水平变位の関係が安定しており、水平 2 方向の降伏耐力の相関関 倸が円形であるため、2 方向加振の免震層の水平变位応答に及ぼす 影響は大きいと考えられる。主軸方向に変換した地震動を用いた、 すべり支承(部材 U)の地震応答解析の結果、主軸方向の応答計算結 果と実験結果が良く対応し、主軸方向で検討することにより、2 方 向加振の最大水平変位が評価できることを確認した。

\section{2)免震層応答への鉛直動の影響}

a)1995 神戸海洋気象台の鉛直動には低振動数域の成分が多いのに対 し、1940 El Centro 地震動では、8〜13Hz の成分が多い。転がり支承 (部材 $\mathrm{T}$ )と亣么弾性支承(部材 $\mathrm{W}$ )を有する免震層の鉛直方向の共振

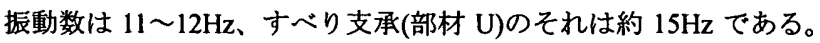
1940 El Centro 地震動で、転がり支承とゴム弾性支承における免震層 の鉛直加速度が大きくなる。その理由は鉛直動の振動数成分と免震 層の共振現象である。

b) 2 方向加振における免震層の水平加速度の最大值に対し、3 方向 加振では最大水平加速度が最大 $18 \%$ 程度增加する。一方、免震層の 最大水平変位の増加は見られなかった。これは免震層の水平加速度 は鉛直動の影響を受けるためであり、鉛直動が作用すると、免震層 の水平加速度が若干增加する。しかし、その增加分の大きさは免震 層の最大水平加速度に比べてわずかであること、またその増加分の 成分は高振動数であることから、鉛直動が免震層の水平変位に及ほ 寸影響は小さいと判断される。

\section{謝辞}

本研究は、建設省建築研究所(現、独立行政法人建策研究所)と(社) 建築研究振興協会との共同研究「住宅用兔震技術の開発(免震住宅研 究委員会) (委員長 : 山口昭一博士・(株)東京建築研究所長)」ににおい て実施されたものである。関係各位に感謝いたします。また、3 次 元振動台の使用においてご協力頂きました田村敬一上席研究員(独 立行政法人土木研究所)、東拓生専門員(国土交通省関東地方整備局 常総国道事務所)、実験データの収録・整理に際してご協力頂きまし たDr. Bujar Myslimaj (McMaster University, Ontario, Canada)に感謝致 します。

\section{参考文献}

1) 阪神・淡路大震災災害調査報告編集委員会 : 阪神・淡路大震災 災害調查報告 共通編-1 総集編, 日本建築学会, pp.59-62, 2000.3

2) 日本建筑学会建築計画委員会兵庫県南部地震調查研究部会建築 内部空間における WG : 阪神大震災住宅内部被害調查報告書,
1996.9

3）日本建筑センター：免震椿造建築物-その技術開発と地震観測結 果 PART 2 -、1995.6

4）飯場正紀、山内泰之、緑川光正他 : 住宅の免震化に関寸る研究 (その 1 ) 住宅の免震化における検討項目、日本建築学会大会学 術講演梗概集、樓造 II、pp.687-688、1997.9

5) Masanori liba, Hiroyuki Yamanouchi, Mitsumasa Midorikawa, et al.: Research on Performance of Base Isolated House, Proceedings of the Second World Conference on Structural Control (2WCSC), Kyoto, Japan, pp.1119-1126, 1998.6

6）平野茂、三宅辰哉、深堀美英他 : 実大振動実験に基づく木造免 震住宅の地震応答評価手法に関する研究、その 1 実験結果ならび に 1 質点振動モデルを用いた解析的考察、日本建策学会構造系論 文集、No.529、pp.65-72、2000.3

7) 古橋剛：シリーズ免震関連部材-(6) 戸建住宅用免震装置-2、 mensin、(社)日本兔震構造協会、No.29、pp.23-30、2000.8

8) 三浦義勝、箭野憲—: : シリーズ免震関連部材-(7) 戸建住宅用免 震装置-3、 mensin 、(社)日本免震構造協会、No.30、pp.24-29、 2000.11

9）福田一郎、飯場正紀、緑川光正他 : 住宅の免震化に関する研究 (その 2 ) 兔震住宅モデルの振動台実験、日本建築学会大会学術 講演梗概集、構造 II、pp.689-690、1997.9

10)飯場正紀、緑川光正他：戸建住宅用免震装置の振動台実験、日 本建築学会大会学術講演梗概集、構造 B- II 、pp.661-662、1998.9

11) 日本建築学会: 免震構造設計指針、pp.102-104、pp.330-336、2001.9

12)建設省 (現独立行政法人) 土木研究所 :「3 次元大型振動台」パン フレット

13)飯場正紀、緑川光正他 : 住宅用免震装置の 3 次元振動台実験(そ の 1)(その 2)、日本貄築学会大会学術講演梗概集、構造 B-II、 pp.741-744、751-752、1999.9

14) Bujar Myslimaj, Mitsumasa Midorikawa, Masanori liba, et al.: Seismic behavior of a newly developed base isolation system for houses, Journal of Asian Architecture and Building Engineering, Vol.1, No.2, pp.17-24, 2002.11

\section{付録}

付図 1 に、免震部材 $\mathrm{R}$ (転がり支承)および $\mathrm{S}$ (すべり支承)における 免震層のせん断力係数一水平变位の関係を示す。
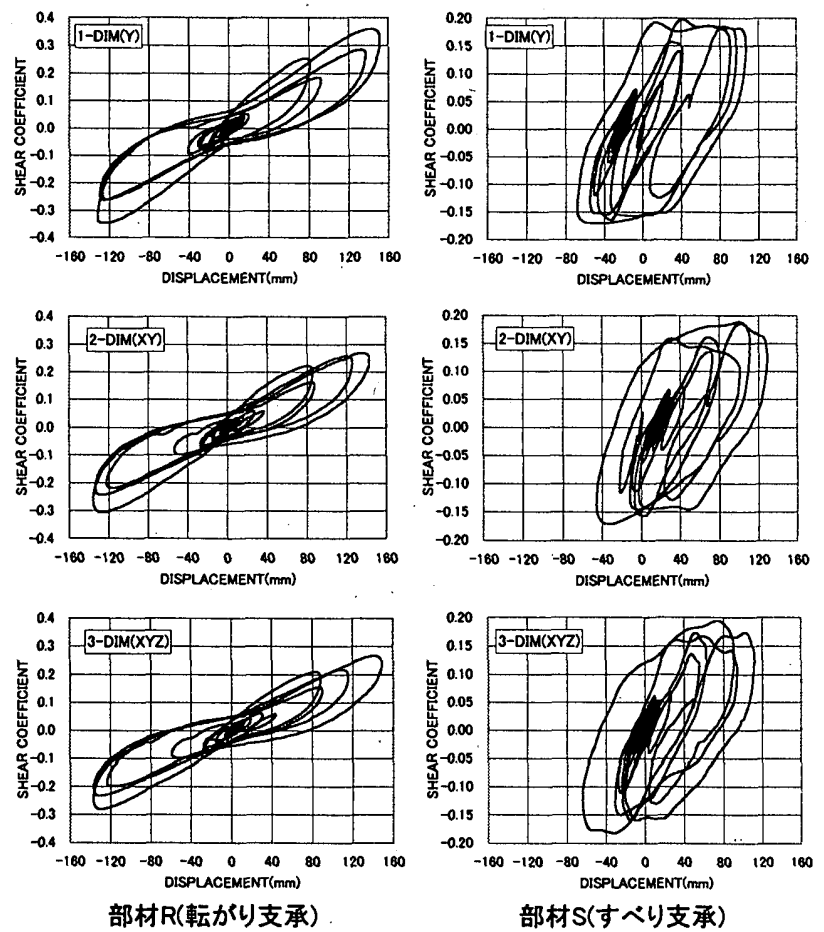

付図 1 地震動の加振次元数の違いによるY 方向の免震層の せん断力係数一水平変位の関係(1995 神戸海洋気象台 $50 \mathrm{~cm} / \mathrm{s}$ ) 